American Journal of Biochemistry and Biotechnology 6 (1): 11-18, 2010

ISSN 1553-3468

(C) 2010 Science Publications

\title{
Modulation of Insulin Receptor Substrate-1 and Some Inflammatory Variables in Hyperinsulinemic Rats Treated with Cinnamon Extract
}

\author{
${ }^{1}$ Mohamed H. Mahfouz, ${ }^{2}$ Hala M. Ghanem and ${ }^{3}$ Mona A. Mohamed \\ ${ }^{1}$ Department of Biochemistry, National Institute of Diabetes and Endocrinology, Cairo, Egypt \\ ${ }^{2}$ Department of Biochemistry, Faculty of Science, Ain Shams University, Egypt \\ ${ }^{3}$ Biochemistry Division, Department of Chemistry, Faculty of Science, Al-Azhar University, Egypt
}

\begin{abstract}
Cinnamon Extract (CE) has shown to be generally safe when ingested and to have many pharmacological properties. Problem statement: Study the effects of daily intake of CE on the modulation of hepatic, cardiac Insulin Receptor Substrate-1 (IRS-1) and their relations to some inflammatory variables in hyperinsulinemic rats. Approach: The influence of CE administered orally was studied in hyperinsulinemic rats. Eighteen male Wistar rats were divided into 3 groups of 6 rats each. Group 1; control animals received starch as control diet, while group 2; rats were fed a "highfructose diet" (60\%). Group 3; fructose-fed rats received orally CE $(0.5 \mathrm{~mL} / \mathrm{rat} /$ day $)$ from the 16 th day of fructose feeding in experimental period. The animals were maintained in their respective groups for 30 days. At the end of the experimental period, serum levels of glucose, insulin, lipid profile, Total Antioxidant Capacity (TAC), Malondialdehyde (MDA), sialic acid and soluble Fas (sFas) were assayed. Hepatic and cardiac IRS-1 levels were also evaluated. Results: Fed high fructose diet to rats induced significant elevations in serum levels of glucose, insulin, triacylglycerol, HDL-c, sialic acid, sFas and MDA, while the level of serum TAC was significantly reduced as compared to controls. Also significant reduction in the levels of hepatic and cardiac IRS-1 were recorded as compared to controls. Oral administration of cinnamon extract to fructose-fed rats alleviated the effects of fructose and these rats showed a normal level of the parameters studied. The percentage changes of IRS-1 level in fructose-fed rats before and after treatment with CE were 38.51 for liver and $31.92 \%$ for cardiac muscle. This increase in IRS-1 level after treatment is still lowered than control level with the percentage change -11.82 and $-9.93 \%$ for liver and cardiac muscle respectively. There was a significant positive correlation between IRS-1 and TAC level whereas there was negative correlation between IRS-1 and MDA, sialic acid and sFas. Conclusion: This study reports interest findings that cinnamon extract enhances glucose uptake by activating insulin receptor kinase activity in rats fed high fructose diet and it has additional roles as antioxidant and anti-inflammatory agents. Thus, clinical application of cinnamon could be considered as a potential therapeutic option in humans in the treatment of insulin resistance states. So inclusion of cinnamon in the daily diet could be recommended.
\end{abstract}

Key words: Cinnamon, fructose fed rats, insulin receptor substrat-1, inflammatory markers

\section{INTRODUCTION}

It has been established that insulin resistance occurs in rats fed high fructose diet in which insulin actions were impaired. Although various defects in insulin action have been reported in animals, the exact mechanisms involved in the insulin resistance have not been adequately defined (Carvalho et al., 1996). Insulin initiates its metabolic and growth promoting effects by binding to $\alpha$-subunit of its tetrameric receptors thereby activating the kinase in the $\beta$ subunit. This interaction catalyses the intramolecular autophosphorylation of specific tyrosine residues of the $\beta$ subunit which farther enhances the tyrosine kinase activity of the receptor toward other protein substrates (White and Kahn, 1994). In most cells, this primary events leads to the subsequent tyrosyl phosphorylation to a cytoplasmic protein with an apparent molecular weight of 160-185 KDa, called insulin receptor substrate-1 (IRS-1) (Sun et al., 1991). Considerable evidence indicates that insulin receptor tyrosine kinase and associated IRS-1 phosphorylation are essential for many of the biological effects of insulin.

Corresponding Author: Mohamed H. Mahfouz, Department of Biochemistry, National Institute of Diabetes and Endocrinology, Cairo, Egypt Tel: +202 24090447 
An impairment of insulin action (insulin resistance) is involved in many diseases including non-insulin dependent diabetes, obesity and cardiovascular diseases (O'Doherty et al., 1997). It has long been known that rats fed high fructose diet develops a cluster of abnormalities and provide an animal model of insulin resistance associated with hyperinsulinemia, hypertriglyceridemia, glucose intolerance and hypertension (Thorbun et al., 1989; Reaven, 1991). Insulin resistance also could promote inflammation by increased oxidative stress (Baynes and Thorpe, 1999). Inflammatory and resident cells (endothelial and vascular smooth muscle cells) release different proteins that can generate a chronic inflammatory response in the injured artery. Measurement of circulating markers of inflammation may provide some insight into this process. Proteins secreted by cells implicated in atherosclerotic lesions, including soluble Fas (sFas) and soluble Fas Ligand (Fas L), circulate in small amount, but can be detected. In particular Fas-mediated apoptosis has been reported to be involved in vessel wall remodeling in response of hypertension (Xu et al., 2001). Oxidative stress is critical part of the apoptoting agent, antioxidants can inhibit or delay oxidative stress induced apoptosis (Jabs, 1999). Serum sialic acid (Nacetyl neuraminic acid) concentration is also a marker of acute phase response and may be used as an inflammatory marker and indicator for microvascular diseases (Nayak and Roberts, 2006).

It has been reported by López et al. (2005) that Cinnamon Extract (CE) has shown to be generally safe when ingested and to have many pharmacological properties, such as antibacterial effects. Cinnamon polyphenols may have additional benefits for human health and has the ability to inhibit cancer cell proliferation by altering the cell cycle pattern in three myeloid cell lines (Cao et al., 2007). Khan et al. (1990) have reported that unidentified factor is present in cinnamon that potentiates the action of insulin in carbohydrate metabolism. They termed this factor as Insulin Potentiating Factor (IPF). Broadhurst et al. (2000) are confirmed the presence of this factor in cinnamon. This hypoglycemic effect of cinnamon may or may not be like other hypoglycemic drugs. This unidentified factor increased the activity of insulin 3 fold in glucose metabolism in rat. Anderson et al. (2006) characterized this unidentified factor present in cinnamon as Methyl Hydroxyl Chalcone Polymers (MHCP). This responsive to insulin by activating the enzyme that causes insulin to bind to cells (insulin receptor kinase) and inhibiting the enzyme that blocks this process (insulin receptor phosphatase) leading to maximal phosphorylation of the insulin receptor which associated with increased insulin sensitivity.
The study was designed to investigate the effects of daily intake of an aqueous Cinnamon Extract (CE) on the modulation of hepatic and cardiac Insulin Receptor Substrate-1(IRS-1). It was extended to study the relation between this receptor and some inflammatory variables such as sialic acid and soluble Fas (sFas) in hyperinsulinemic rats.

\section{MATERIALS AND METHODS}

Chemicals and plant: All chemicals and solvents were of high analytical grade and were purchased from Sigma Chemical Company. Cinnamon bark (Cinnamon zeylanicum) was purchased from the local market. The bark was dried and finely powdered in a mechanical mixer. About $10 \mathrm{~g}$ of finely-powdered cinnamon was weighed and mixed with $100 \mathrm{~mL}$ of water and kept in a water bath at $60^{\circ} \mathrm{C}$ for $2 \mathrm{~h}$ and filtered. This extract was diluted with water (1:10) and was administered orally to rats (Kannappan et al., 2006).

Animals and treatment: Eighteen adult male Wistar rats of body weight ranging from 120-160 g were purchased from the breeding unit of the Egyptian Organization for Biological Products and Vaccines (Helwan, Egypt). They were housed 2/cage under controlled condition $12 \mathrm{~h}$ light/12 h dark cycle. All animals received standard pellet diet for one week and water ad libitum. Approval had been taken from the Research Ethical Committee of General Organization of Teaching Hospitals and Institutes, Cairo, Egypt. Insulin resistance was induced by feeding high fructose diet $(60 \mathrm{~g} / 100 \mathrm{~g})$. After acclimatization, the animals were divided into 3 groups consisting of 6 rats each and were maintained as follows:

Group 1: $(\mathrm{CON}) /$ control animals received the control diet which contained corn starch $(60 \%)$ as a sole source of carbohydrate, $20 \%$ casein, $0.7 \%$ methionine, $5 \%$ groundnut oil, $10.5 \%$ wheat bran and $3.5 \%$ salt mixture and water ad libitum. Vitamin mixture $(0.2 \mathrm{~mL})$ was added per kg feed.

Group 2: (FRU)/fructose-fed rats received a highfructose diet and tap water ad libitum. The high-fructose diet was similar in composition to the control diet except that starch was replaced by fructose $(60 \%)$.

Group 3: $(F R U+C E) /$ fructose-fed rats received orally $\mathrm{CE}$ extract $(0.5 \mathrm{~mL} / \mathrm{rat} / \mathrm{day})$ from the $16 \mathrm{th}$ day of fructose feeding in experimental period. 
The animals were maintained in their respective groups for 30 days and body weight changes were measured weekly.

Blood sampling and processing: At the end of the experiment period, rats were fasted overnight and blood samples were taken from the retro-orbital venous plexus under light ether anesthesia. Serum was separated by centrifugation at $3000 \mathrm{rpm}$ for $10 \mathrm{~min}$. and used for determination of glucose, total cholesterol, triacylglycerol and HDL-c using the methods described by Barham and Trinder (1972); Allain et al. (1974); Fossati and Prencipe (1982) and Finley et al. (1978) respectively. LDL-c was calculated by the Friedewald et al. (1972) formula. Atherogenic index was calculated from ratio of total cholesterol/HDL-c (Wilson et al., 1980). The remaining part of serum was stored at $-80^{\circ} \mathrm{C}$ until analysis of insulin, Total Antioxidant Capacity (TAC), Malondialdehyde (MDA), sialic acid and soluble Fas (sFas). Levels of serum insulin was assayed by monoclonal immunoradiometric assay using kit supplied by Diagnostic Products Corporation (DPC) according to Marschner et al. (1974). Homeostasis Model Assessment (HOMA) correlates positively with insulin-resistance and was calculated according to Matthews et al. (1985). Total antioxidant capacity was determined according to the method of Koracevic et al. (2001). Malondialdehyde (MDA) concentration was determined fluorometrically according to the method of $\mathrm{Li}$ and Chow (1994) with excitation at $515 \mathrm{~nm}$ and emission at $550 \mathrm{~nm}$ after isobutyl alcohol extraction. Serum sialic acid was measured by a spectrophotometric assay according to the method of Warren (1959). sFas concentration was assessed using the Enzyme-Linked Immunosorbent Assay (ELISA) kit (Research and Diagnostic Systems, Minneapolis, USA) according to the manufacturer's instructions. Western blot analysis was used to determine Insulin Receptor Substrate-1 (IRS-1) according to the method of Bezerra et al. (2000). Briefly, the liver and heart were excised and homogenized in extraction buffers at $100^{\circ} \mathrm{C}$ for $5 \mathrm{~min}$. After centrifugation, aliquots with same amount of protein were resolved on 6\% SDS-polyacrylamide gel, transferred to nitrocellulose and detected with anti-IRS-1 antibody.

Statistical analysis: All results were expressed as the mean \pm SD. Statistical analysis was performed with Statistical Package for the Social Science for windows (SPSS, version 11.0, Chicago, IL, USA). The data were analyzed by one-way Analysis Of Variance (ANOVA). To compare the difference among the groups, post hoc testing was performed by the Bonferroni test. Pearson's correlation analysis was used to determine the correlation among the parameters assessed. The p-value less than 0.05 was considered statistically significant (Dawson and Trapp, 2001).

\section{RESULTS}

The levels of serum glucose, insulin and HOMA index are shown in Table 1. There were significant elevations in glucose, insulin levels and HOMA index after 30 days of fructose-feeding rats (FRU group) $(\mathrm{p}<0.0001$ for each) compared to control animals. Cinnamon extract administration to fructose fed rats (FRU $+\mathrm{CE}$ at 16th days) cause a significant reduction in the three pervious parameters $(\mathrm{p}<0.0001$ for each), compared to FRU-group.

Table 2 showed a significant reduction in the levels of hepatic and cardiac IRS-1 in rats fed high fructose diet, compared to controls with percentage changes -36 and $-32 \%$, respectively. Oral administration of CE to fructose-fed rats increased the levels of IRS-1 in liver and cardiac muscle with percentage changes 38.51 and $31.92 \%$, respectively compared to FRU group. Although this increase in IRS-1 level after treatment is toward the normal control, but still lower with percentage changes -11.82 and $-9.93 \%$ for liver and cardiac muscle respectively.

Table 1: Serum levels of glucose, insulin and HOMA index in experimental groups (Means \pm SD)

\begin{tabular}{llll}
\hline & Experimental groups & \\
& & & FRU + CE \\
Parameters & CON & FRU & at 16th day \\
\hline F.Glucose $\left(\mathrm{mg} \mathrm{dL}^{-1}\right)$ & $83.80 \pm 19.0$ & $134.20 \pm 17.4^{\mathrm{a}}$ & $78.7 \pm 3.2^{\mathrm{b}}$ \\
Insulin $\left(\mathrm{IU} \mathrm{mL} \mathrm{mL}^{-1}\right)$ & $16.00 \pm 2.3$ & $35.80 \pm 4.4^{\mathrm{a}}$ & $15.9 \pm 1.7^{\mathrm{b}}$ \\
HOMA index & $3.23 \pm 0.76$ & $11.82 \pm 2.75^{\mathrm{a}}$ & $3.0 \pm 0.89^{\mathrm{b}}$ \\
\hline HOMA
\end{tabular}

HOMA: Homeostasis model assessment; ${ }^{a}: p<0.0001$ Vs $\mathrm{CON}^{\text {b }}{ }^{\mathrm{b}}$ : $\mathrm{p}<0.0001$ Vs FRU

Table 2: Insulin Receptor Substrate-1 (IRS-1) $\left(\mu \mathrm{g} \mathrm{mL}^{-1}\right)$ in experimental groups (Means \pm SD)

Experimental groups

\begin{tabular}{llll} 
& & & \\
Tissues & CON & FRU & $\begin{array}{l}\text { FRU + CE } \\
\text { at 16th day }\end{array}$ \\
\hline $\begin{array}{l}\text { Liver } \\
\text { Mean } \pm \text { SD }\end{array}$ & $4.65 \pm 0.60$ & $2.96 \pm 0.32^{\mathrm{a}}$ & $4.10 \pm 0.41^{\mathrm{b}}$ \\
$\begin{array}{l}\text { Change (\%) } \\
\text { Vs CON }\end{array}$ & & $-36 \%$ & $-11.82 \%$ \\
$\begin{array}{l}\text { Vs FRU } \\
\text { Cardiac muscle }\end{array}$ & & & $38.51 \%$ \\
$\begin{array}{l}\text { Mean } \pm \text { SD } \\
\text { Change (\%) }\end{array}$ & $3.12 \pm 0.29$ & $2.13 \pm 0.32^{\mathrm{a}}$ & $2.81 \pm 0.29^{\mathrm{b}}$ \\
Vs CON & & & $-9.93 \%$ \\
Vs FRU & & $-32 \%$ & $31.92 \%$ \\
\hline${ }^{\mathrm{a}}: \mathrm{p}<0.0001 \mathrm{Vs}_{\mathrm{C}} \mathrm{CON}{ }^{\mathrm{b}}{ }^{\mathrm{b}}: \mathrm{p}<0.001 \mathrm{Vs}$ FRU &
\end{tabular}


Am. J. Biochem. \& Biotech., 6 (1): 11-18, 2010

Table 3: Serum lipid profile in experimental groups (Means \pm SD)

\begin{tabular}{|c|c|c|c|}
\hline \multirow[b]{2}{*}{ Parameters } & \multicolumn{3}{|c|}{ Experimental groups } \\
\hline & $\mathrm{CON}$ & FRU & $\begin{array}{l}\text { FRU + CE } \\
\text { at 16th day }\end{array}$ \\
\hline Cholesterol $\left(\mathrm{mg} \mathrm{dL}^{-1}\right)$ & $70.7 \pm 7.2$ & $81.50 \pm 10.8$ & $69.78 \pm 4.89$ \\
\hline Triacylglycerol $\left(\mathrm{mg} \mathrm{dL}^{-1}\right)$ & $69.2 \pm 7.1$ & $161.60 \pm 60.5^{\mathrm{a}}$ & $80.63 \pm 6.41^{\mathrm{b}, \mathrm{d}}$ \\
\hline HDL-c $\left(\mathrm{mg} \mathrm{dL}^{-1}\right)$ & $31.2 \pm 1.2$ & $37.20 \pm 1.5^{\mathrm{d}}$ & $34.20 \pm 3.91$ \\
\hline LDL-c $\left(\mathrm{mg} \mathrm{dL}^{-1}\right)$ & $25.8 \pm 1.3$ & $26.70 \pm 1.9$ & $21.50 \pm 3.02^{\mathrm{c}, \mathrm{d}}$ \\
\hline T. cholesterol/HDL-c & $2.3 \pm 0.23$ & $2.18 \pm 0.29$ & $2.08 \pm 0.36$ \\
\hline
\end{tabular}

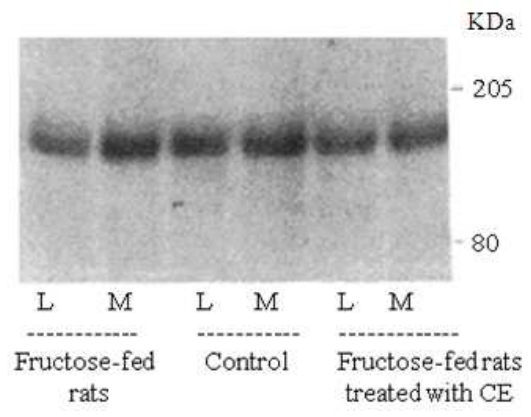

Fig. 1: IRS-1of liver and muscle in fructose-fed rats, controls, fructose-fed rats treated with CE. Liver and muscle lysates were immunoprecipitated with an anti-IRS-1 antibody and IRS-1 activity was measured (lane L: Liver, lane M: Cardiac muscle)

Table 3 demonstrates that high fructose diet (FRU) induced marked elevation in serum level of triacylglycerol which amounted $(161.6 \pm 60.5, \mathrm{p}<0.0001)$ compared to control rats, whereas the levels of cholesterol, low density lipoprotein cholesterol (LDL-c) did not show any significant alteration in FRU group compared to control one. As regard to $\mathrm{CE}$ group, significant decrease in serum triacyglycerol $(\mathrm{p}<0.03$ for each) and LDL-c $(p<0.003)$ were observed compared to fructose-fed rats group.

Fed high fructose diet to rats induced significant increases in serum levels of MDA (15.33 \pm 2.4$)$, sialic acid $(1.75 \pm 0.51)$ and soluble Fas $(27.6 \pm 1.9)(\mathrm{p}<0.0001$ for each), while TAC level represent a marked reduction $(0.53 \pm 0.22, \mathrm{p}<0.01)$ compared to rats fed control diet (Table 4). Oral administration of cinnamon extract to fructose feeding rats improved these parameters toward the control levels.

Immunoblotting showed that levels of IRS-1 were decreased in both liver and heart of rats fed high fructose diet, while these levels were significantly increased following treatment of animals with cinnamon extract, compared to control animals (Fig. 1).
Table 4: Serum levels of Total Antioxidant Capacity (TAC), Malondialdehyde (MDA), sialic acid and soluble Fas (sFas) in experimental groups (Means $\pm \mathrm{SD}$ )

\begin{tabular}{llcc}
\hline & \multicolumn{2}{l}{ Experimental groups } & \\
& & & $\begin{array}{l}\text { FRU + CE } \\
\text { Parameters }\end{array}$ \\
CON & FRU & at 16th day \\
\hline TAC $\left(\mathrm{mM} \mathrm{L}^{-1}\right)$ & $0.82 \pm 0.068$ & $0.53 \pm 0.22^{\mathrm{a}}$ & $0.78 \pm 0.12^{\mathrm{d}}$ \\
MDA $\left(\mathrm{nmol} \mathrm{mL}^{-1}\right)$ & $7.56 \pm 1.57$ & $15.33 \pm 2.4^{\mathrm{b}}$ & $7.40 \pm 1.3^{\mathrm{c}}$ \\
Sialic acid $\left(\mathrm{mmol} \mathrm{L}^{-1}\right)$ & $0.32 \pm 0.067$ & $1.75 \pm 0.51^{\mathrm{b}}$ & $0.36 \pm 0.055^{\mathrm{c}}$ \\
sFas $\left.(\mathrm{ng} \mathrm{mL})^{-1}\right)$ & $19.10 \pm 1.1$ & $27.60 \pm 1.9^{\mathrm{b}}$ & $20.20 \pm 1.22^{\mathrm{c}}$ \\
\hline
\end{tabular}

sFas: Soluble form of Fas; ${ }^{\mathrm{a}}: \mathrm{p}<0.01 \mathrm{Vs} \mathrm{CON} ;^{\mathrm{b}}: \mathrm{p}<0.0001 \mathrm{Vs} \mathrm{CON}$; c: $p<0.0001$ Vs FRU; ${ }^{d}$ : $p<0.04$ Vs FRU

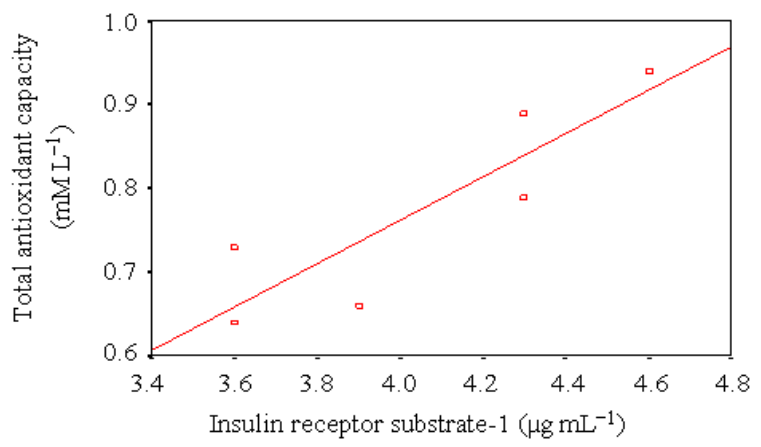

Fig. 2: Correlation between liver IRS-1 and TAC in fructose-fed rats treated with $\mathrm{CE} ;(\mathrm{r}=0.880$, $\mathrm{p}=0.02$ )

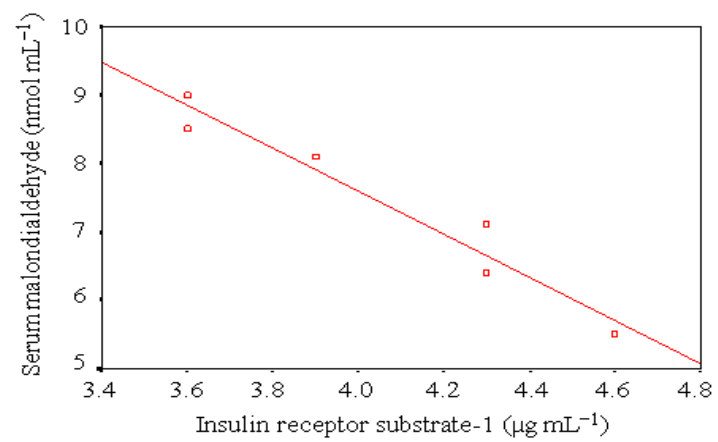

Fig. 3: Correlation between liver IRS-1 and MDA in fructose-fed rats treated with $\mathrm{CE} ;(\mathrm{r}=-0.972$, $\mathrm{p}=0.0001)$

In fructose fed rats treated with $\mathrm{CE}$ on 16th day, there was a significant positive correlation between hepatic IRS-1 and TAC level $(r=0.880, p=0.02)$ (Fig. 2), whereas there was negative correlation between hepatic IRS-1 and MDA $(r=-0.972$, $\mathrm{p}=0.0001)$, sialic acid $(\mathrm{r}=-0.955, \mathrm{p}=0.003)$ and $\mathrm{sFas}$ $(r=-0.944, p=0.002)$ (Fig. 3-5). Cardiac IRS-1 showed non significant correlations with the pervious parameters. 
Am. J. Biochem. \& Biotech., 6 (1): 11-18, 2010

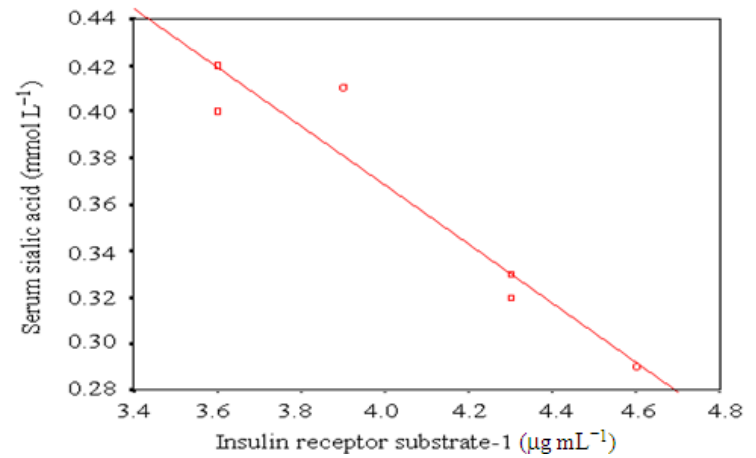

Fig. 4: Correlation between liver IRS-1 and serum sialic acid in fructose-fed rats treated with $\mathrm{CE}$; $(\mathrm{r}=-0.955, \mathrm{p}=0.003)$

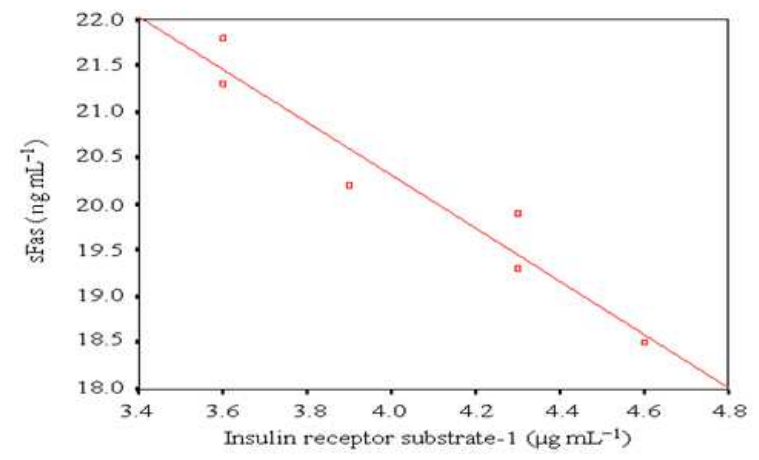

Fig. 5: Correlation between liver IRS-1 and sFas in fructose-fed rats treated with CE; $(r=-0.944$, $\mathrm{p}=0.002$ )

\section{DISCUSSION}

The insulin resistance in animals fed a high fructose diet is associated with glucose intolerance, increased insulin concentrations and decreased sensitivity to insulin (Limura et al., 1995). The present results showed a state of moderate insulin resistance in fructose-fed rats, as demonstrated by significant elevation of serum glucose, insulin levels and higher value of HOMA index as compared with control fed rats. Fructose-fed rats have an impaired ability to suppress hepatic glucose production and to eliminate peripheral glucose, an increase in the gluconeogenic enzymes glucose-6-phosphatase and phospho-enolpyruvate carboxylase has been reported for the liver of these animals (Van Weeren et al., 1998). High fructose diet also up regulates lipogenesis pathway which leads to increased production of triacylglycerols and HDL-c as demonstrated in this study. Moore et al. (2000) reported that triacylglycerols accumulation contributes to hepatic insulin resistance and glucose intolerance.
Insulin resistance has been attributed to a low level of insulin-stimulated glucose oxidation due to modifications in the post-receptor cascade of insulin action (Catena et al., 2003).

In this study, there was a significant reduction in the levels of hepatic and cardiac IRS-1 tyrosine phosphorylation in rats fed high fructose diet, compared to controls with percentage changes -36 and $-32 \%$, respectively. This is in agreement with the report of Bezerra et al. (2000) who stated that there was a significant reduction in the level of hepatic and muscle IRS-1 tyrosine phosphorylation, followed by a reduction in IRS-1/PI3-kinase association in liver and muscle. The decrease observed in this study may be of biological importance because a reduction of receptor phosphorylation has been correlated with insulin resistance in different animal models (Saad et al., 1997). These results differed from those of Deutsch et al. (1993) who reported no change in insulin receptor kinase activity in fructose-fed rats. Catena et al. (2003) concluded that the decreased number of insulin receptors occurring at the level of gene expression is present in skeletal muscles and liver of fructose-fed rats and might contribute to insulin resistance in his model.

In the present study, the effects of oral treatment with CE extract to rats fed high-fructose diet were pronounced by improvement of insulin resistance. This indicated by enhancing the glucose utilization and improves lipid profile. Broadhurst et al. (2000) reported that cinnamon extract has been shown to have insulin like biological activity and this extract stimulated glucose uptake, glycogen synthesis and activated glycogen synthase (Jarvill-Taylor et al., 2001).

Increasing evidence suggests that aqueous $\mathrm{CE}$ mimic some of the effects of insulin and improve insulin action (Broadhurst et al., 2000; Jarvill-Taylor et al., 2001). Cinnamon has been shown to reduce fasting serum glucose, triacylglycerol, total cholesterol and LDL-c in patients with type 2 by its lipolytic activity and animals by inhibiting hepatic 3-Hydroxy-3-Methyl Glutaryl Co-enzyme A (HMG-Co A) reductase activity (Lee et al., 2003).

The improvement of insulin receptor was noticeable and pronounced in the present study after treated the rats fed high-fructose diet with cinnamon extract. This indicated by elevation in IRS-1 levels in liver and cardiac muscle as compared with FRU group (percentage changes 38.51 and $31.92 \%$, respectively). Although this increased after treatment is toward the normal control level, but still lower with percentage changes -11.82 and $-9.93 \%$ for liver and cardiac muscle respectively. 
Hlebowicz et al. (2007) reported that cinnamon has been shown to improve insulin receptor function by activating insulin receptor PI3-kinase and inhibiting tyrosine phosphatase. Cinnamon has also been shown to stimulate the insulin receptor activity by increasing the concentrations of the phosphorylated intracellular protein IRS-1 and increasing the binding to PI3-kinase, which leads to enhanced cellular glucose uptake (Qin et al., 2003). It has been shown that cinnamon prevents the development of insulin resistance in fructose-fed rats by enhancing the insulin signaling, possibly via the nitric oxide pathway in skeletal muscle (Qin et al., 2004).

Hyperglycemia and insulin resistance induced by feeding high-fructose diet could promote inflammation by increased oxidative stress. In the present study, there was an impairment of antioxidant defense systems in fructose fed rats. This indicated by pronounced decrease in serum Total Antioxidant Capacity (TAC), while lipid peroxidation as MDA was statistically increased, compared to control rats. These findings are in agreement with the suggestion of Ceriello (1997) who found that acute hyperglycemia provokes oxidative stress which leads to depletion of antioxidant capacity.

With regard to the inflammatory variables, the present results revealed that feeding high-fructose diet to rats induced significant elevations in the levels of sialic acid and apoptotic (sFas) marker, compared to these fed control diet. The present result of sialic acid was in agreement with reports of Cylwik et al. (2006) and Nayak and Roberts (2006) who stated that the increased level of sialic acid was strongly related to the presence of microvascular complications and cardiovascular risk factor like hypertension. The increased level of sFas may be associated with hypertension which induced by feeding high-fructose diet to rats. Blanco-Colio et al. (2007) reported that sFas concentrations are elevated in patients with different cardiovascular risk factors suggesting that sFas may be a novel marker of vascular damage. Ceriello et al. (2002) reported that high serum glucose may produce myocardial damage and cardiac cell apoptosis through a formation of nitrotyrosine, which leads to increase Fas/Fas-ligand system in uncontrolled apoptosis.

The present research focuses on the effects of cinnamon treatment on the insulin resistance model, the results revealed that $\mathrm{CE}$ alleviated the antioxidant systems and improve the inflammation which induced by feeding high-fructose diet to rats. These improvements were indicated by the levels of TAC and MDA as well as sialic acid and sFas that reaching nearly to the normal control levels. Cao et al. (2007) reported that cinnamon bark has antioxidant effects by increasing the activities of antioxidant enzymes including glutathione-S-transferase, superoxide dismutase and catalase in rats livers and hearts. Anderson et al. (2004) discovered the scientific evidence that how cinnamon serves as an important antioxidant. Cao et al. $(2006,2007)$ reported that CE may have anti-inflammatory properties because insulin induces the mRNA levels of the anti-inflammatory protein Tristetraprolin (TTP). In fructose-fed rats treated with $\mathrm{CE}$ on 16th day, there was a significant positive correlation between IRS-1 and TAC level, whereas there was negative correlation between IRS-1 and MDA, sialic acid and sFas. These results confirm that $\mathrm{CE}$ has insulin like activity which leading to modulation in the steps of insulin signal.

\section{CONCLUSION}

In conclusion, this study reports interest findings that cinnamon extract enhances glucose uptake by activating insulin receptor kinase activity in rats fed high fructose diet and it has additional roles as antioxidant and anti-inflammatory agents and it has the ability to inhibit cancer cell proliferation. Thus, clinical application of cinnamon could be considered as a potential therapeutic option in humans in the treatment of insulin resistance states. So inclusion of cinnamon in the daily diet could be recommended.

\section{REFERENCES}

Allain, C.C., L.S. Poon, C.S.G. Chan and W. Richmond et al., 1974. Enzymatic determination of total serum cholesterol. Clin. Chem., 20; 470-475. PMID: 4818200

Anderson, R.A., C.L. Broadhurst, M.M. Polansky, W.F. Schmidt and A. Khan et al., 2004. Characterization of polyphenol type-A polymers from cinnamon with insulin-like biological activity. J. Agric. Food Chem., 52: 65-70. DOI: 10.1021/jf034916b

Anderson, R.A., C.L. Broadhurst, M.M. Polansky, W.F. Schmidt and A. Khan et al., 2006. Isolation and characterization of chalcone polymer from cinnamon with insulin like biological activity. Am. J. Clin. Nutr., 84: 1432-1436.

Barham, D. and P. Trinder, 1972. An improved color reagent for the determination of blood glucose by the oxidase system. Analyst, 97: 142-145. PMID: 5037807 
Baynes, J.W. and S.R. Thorpe, 1999. Role of oxidative stress in diabetic complications: A new perspective on an old paradigm. Diabetes, 48: 1-9. DOI: 10.2337/diabetes.48.1.1

Bezerra, R.M., M. Ueno, M.S. Silva, D.Q. Tavares and C.R. Carvalho et al., 2000. A high fructose diet affects the early steps of insulin action in muscle and liver of rats. J. Nutr., 130: 1531-1535. PMID: 10827205

Blanco-Colio, L.M., J.L. Martín-Ventura, E. De Teresa, C. Farsang and A. Gaw et al., 2007. Increased soluble Fas plasma levels in subjects at high cardiovascular risk: Atorvastatin on Inflammatory Markers (AIM) study, a substudy of ACTFAST. Arterioscler Thromb Vasc. Biol., 27: 168-174. DOI: 10.1161/01.ATV.0000250616.26308.d7

Broadhurst, C.L., M.M. Polansky and R.A. Anderson, 2000. Insulin-like biological activity of culinary and medicinal plant aqueous extracts in vitro. J. Agric. Food Chem., 48: 849-852. DOI: 10.1021/jf9904517

Cao, H., L.J. Deterding, J.D. Venable, E.A. Kennington and J.R. Yates et al., 2006. Identification of the anti-inflammatory protein tristetraprolin as a hyperphosphorylated protein by mass spectrometry and site-directed mutagenesis. Biochem. J., 394: 285-297. PMID: 16262601

Cao, H., M.M. Polansky and R.A. Anderson, 2007. Cinnamon extract and polyphenols affect the expression of tristetraprolin, insulin receptor and glucose transporter 4 in mouse 3T3-L1 adipocytes. Arch. Biochem. Biophys., 459: 214-222. DOI: 10.1016/j.abb.2006.12.034

Carvalho, C.R., S.L. Brenelli, A.C. Silva, A.L. Nunes and L.A. Velloso et al., 1996. Effect of aging on insulin receptor, insulin receptor substrate-1 and phosphatidylinositol 3-kinase in liver and muscle of rats. Endocrinology, 137: 151-159. PMID: 8536607

Catena, C., G. Giacchetti, M. Novello, G. Colussi and A. Cavarape et al., 2003. Cellular mechanisms of insulin resistance in rats with fructose-induced hypertension. Am. J. Hypertens, 16: 973-978. PMID: 14573337

Ceriello, A., 1997. Acute hyperglycaemia and oxidative stress generation. Diabet Med., 14: 45-49. DOI: 10.1002/(SICI)1096-

9136(199708)14:3+<S45::AID-DIA444>3.0.CO;2-R

Ceriello, A., L. Quagliaro , M. D’Amico , C. Di Filippo and R. Marfella et al., 2002. Acute hyperglycemia induces nitrotyrosine formation and apoptosis in perfused heart from rat. Diabetes, 51: 1076-1082. DOI: $10.2337 /$ diabetes.51.4.1076
Cylwik, B., L. Chrostek, B. Jakimiuk, A. Popławska and M. Szmitkowski, 2006. Serum level of Sialic Acid (SA) and Carbohydrate-Deficient Transferrin (CDT) in type 2 diabetes mellitus with microvascular complications. J. Clin. Lab. Anal., 20: 68-73. DOI: 10.1002/jcla.20099

Dawson, B., R.G .Trapp, 2001. Basic and Clinical Biostatistics. 3rd Edn., PBL. Lange Medical Books/McGraw-Hill, USA., ISBN: 0838505104.

Deutsch, D.D., K.L. Jen and G. Grunberger, 1993. Regulation of hepatic insulin receptor tyrosine kinase in rat models of mild insulin resistance. $\mathrm{J}$. Lab. Clin. Med., 122: 421-425. PMID: 8228556

Finley, P.R., R.B. Schifman, R.J. Williams and D.A. Lichhti, 1978. Cholesterol in high-density lipoprotein: Use of $\mathrm{Mg} 2+/$ dextran sulphate in its enzymatic measurement. Clin. Chem., 24: 931-933. PMID: 207463

Fossati, P. and L. Prencipe, 1982. Serum triglycerides determined colorimetrically with an enzyme that produces hydrogen peroxide. Clin. Chem., 28: 2077-2080. PMID: 6812986

Friedewald, W.T., R.I. Levy and D.S. Fredrickson, 1972. Estimation of the concentration of lowdensity lipoprotein cholesterol in plasma, without use of the preparative ultracentrifuge. Clin. Chem., 18: 499-502. PMID: 4337382

Hlebowicz, J., G. Darwiche, O. Björgell and L.O. Almér, 2007. Effect of cinnamon on postprandial blood glucose, gastric emptying and satiety in healthy subjects. Am. J. Clin. Nutr., 85: 1552-1556. PMID: 17556692

Jabs, T., 1999. Reactive oxygen intermediates as mediators of programmed cell death in plants and animals. Biochem. Pharmacol., 57: 231-245. DOI: 10.1016/S0006-2952(98)00227-5

Jarvill-Taylor, K.J., R.A. Anderson and D.J. Graves 2001. A hydroxychalcone derived from cinnamon functions as a mimetic for insulin in 3T3-L1 adipocytes. J. Am. Coll. Nutr., 20: 327-336. PMID: 11506060

Kannappan, S., T. Jayaraman, P. Rajasekar, M.K. Ravichandran and C.V. Anuradha, 2006. Cinnamon bark extract improves glucose metabolism and lipid profile in the fructose-fed rat. Singapore Med. J., 47: 858-863. PMID: 16990960

Khan, A., N.A. Bryden, M.M. Polansky and R.A. Anderson, 1990. Insulin potentiating factor and chromium content of selected foods and spices. Biol. Trace. Elem. Res., 24: 183-188. PMID: 1702671

Koracevic, D., G. Koracevic, V. Djordjevic, S. Andrejevic and V. Cosic, 2001. Method for the measurement of antioxidant activity in human fluids. Clin. Pathol., 54: 356-361. DOI: 10.1136/jcp.54.5.356 
Lee, J.S., S.M. Jeon, E.M. Park, T.L. Huh and O.S. Kwon et al., 2003. Cinnamate supplementation enhances hepatic lipid metabolism and antioxidant defense systems in high cholesterol-fed rats. J. Med. Food, 6: 183-191. DOI: 10.1089/10966200360716599.

Li, X.Y. and C.K. Chow, 1994. An improved method for the measurement of malondialdehyde in biological samples. Lipids, 29: 73-75. DOI: 10.1007/BF02537094

Limura, O., K. Shimamoto, K. Matsuda, A. Masuda and H. Takizawa et al., 1995. Effects of angiotensin receptor antagonist and angiotensin converting enzyme inhibitor on insulin sensitivity in fructose-fed hypertensive rats and essential hypertensives. Am. J. Hypertens., 8: 353-357. DOI: 10.1016/0895-7061(94)00245-7

López, P., C. Sánchez, R. Batlle, and C. Nerín, 2005. Solid- and vapor-phase antimicrobial activities of six essential oils: Susceptibility of selected foodborne bacterial and fungal strains. J Agric Food Chem., 53: 6939-6946. DOI: 10.1021/jf050709v

Marschner, I., P. Bottermann, F. Erhardt, R. Linke and G. Löffler et al., 1974. Group experiments on the radioimmunological insulin determination. Horm. Metab. Res., 6: 293-296. PMID: 4413601

Matthews, D.R., J.P. Hosker, A.S. Rudenski, B.A. Naylor and D.F. Treacher et al., 1985. Homeostasis model assessment: Insulin resistance and beta-cell function from fasting plasma glucose and insulin concentrations in man. Diabetologia, 28: 412-419. DOI: $10.1007 / \mathrm{BF} 00280883$

Moore, M.C., A.D. Cherrington, S.L. Mann and S.N. Davis, 2000. Acute fructose administration decreases the glycemic response to an oral glucose tolerance test in normal adults. J. Clin. Endocrinol. Metab., 85: 4515-4519. PMID: 11134101

Nayak, B.S. and L. Roberts, 2006. Relationship between inflammatory markers, metabolic and anthropometric variables in the Caribbean type 2 diabetic patients with and without microvascular complications. J. Inflamm. Lond., 22: 3-17. DOI: 10.1186/1476-9255-3-17.

O’Doherty, R., D. Stein and J. Foley 1997. Insulin resistance. Diabetologia, 40: 10-15. PMID: 9345639

Qin, B., M. Nagasaki, M. Ren, G. Bajotto and Y. Oshida et al., 2003. Cinnamon extract (traditional herb) potentiates in vivo insulinregulated glucose utilization via enhancing insulin signaling in rats. Diabetes Res. Clin. Pract., 62: 139-148. PMID: 14625128
Qin, B., M. Nagasaki, M. Ren, G. Bajotto and Y. Oshida et al., 2004. Cinnamon extract prevents the insulin resistance induced by a high-fructose diet. Horm. Metab. Res., 36: 119-125. DOI: $10.1055 / \mathrm{s}-2004-814223$

Reaven, G.M., 1991. Insulin resistance, hyperinsulinemia, hypertriglyceridemia and hypertension: Parallels between human disease and rodent models. Diabetes Care, 14: 195-202. PMID: 2044435

Saad, M.J., L. Maeda, S.L. Brenelli, C.R. Carvalho and R.S. Paiva et al., 1997. Defects in insulin signal transduction in liver and muscle of pregnant rats. Diabetologia, 40: 179-186. PMID: 9049478

Sun, X.J., P. Rothenberg, C.R. Kahn, J.M. Backer and E. Araki et al., 1991. Nature, Structure of the insulin receptor substrate IRS-1 defines a unique signal transduction protein. 352: 73-77. DOI: 10.1038/352073a0.

Thorbun, A.W., L.H. Storlien, A.B. Jenkins, S. Khouri and E.W. Kraegen, 1989. Fructose-induced in vivo insulin resistance and elevated plasma triglyceride levels in rats. Am. J. Clin. Nutr., 49: 1155-1163. PMID: 2658534

Van Weeren, P.C., K.M. De Bruyn, A.M. De VriesSmits and J. Van Lint et al., 1998. Essential role for Protein Kinase B (PKB) in insulin-induced glycogen synthase kinase 3 inactivation. Characterization of dominant-negative mutant of PKB. J. Biol. Chem., 273: 13150-13156. DOI: 10.1074/jbc.273.21.13150

Warren, L., 1959. The thiobarbiturate assay for sialic acid. J. Biol. Chem., 234: 1971-1975. PMID: 13672998

White, M.F. and C.R. Kahn, 1994. The insulin signaling system. J. Biol. Chem., 269: 1-4. PMID: 8276779

Wilson, P.W., R.J. Garrison, W.P. Castelli, M. Feinleib and P.M. McNamara et al., 1980. Prevalence of coronary heart disease in the framingham offspring study: Role of lipoprotein cholesterols. Am. J. Cardiol., 46: 649-654. PMID: 7416024

$\mathrm{Xu}, \mathrm{C}$., S. Lee, T.M. Singh, E. Sho and X. Li et al., 2001. Molecular mechanisms of aortic wall remodeling in response to hypertension. J. Vasc. Surg., 33: 570-578. PMID: 11241129 